MATEC Web of Conferences 53, 01066 (2016)

DOI: $10.1051 /$ matecconf $/ 20165301066$

(C) Owned by the authors, published by EDP Sciences, 2016

\title{
Research of the Fire Resistance of Translucent and Composite Facade System
}

\author{
Oleg Nedryshkin ${ }^{1, a}$, Artem Krivtcov ${ }^{1}$ and Valerii Pershakov ${ }^{2}$ \\ ${ }^{1}$ St. Petersburg State Polytechnical University, Polytechnicheskaya, 29, St. Petersburg, Russia, 195251, Russia \\ ${ }^{2}$ National Aviation University, Kosmonavta Komarova, 1, Kiev, 03680, Ukraine
}

\begin{abstract}
The paper aims at researching fire resistance of a prototype facade system "Technocom" (type Alucobond A2). Experimental and theoretical research of fire hazard facade system is carried out. The objectives of the study are to determine compliance with the applicable front of special technical requirements. The status of problem reducing fire hazard facade system is reviewed. The method developed by compensatory measures is applied.
\end{abstract}

\section{Introduction}

Nowadays we are witnessing a fast growth in the construction of buildings including facade systems. For the last 10 years translucent and composite facade system used in Russia over than 4 million $\mathrm{m} 2[1,2]$.

The technical regulations about the requirements of fire safety, the limits of fire resistance of construction are defined under the conditions of standard tests. The dynamics of burning, however, is not always possible to standardize due to the variety of architectural, space-planning and construction solutions. Requirements vary depending on classes of buildings fire functional hazard [3-12].

Research papers $[1,2,13-15]$ is consider the natural ventilation of buildings and features some translucent ventilated facades. The problem is suggested for discussion of fireproof glass structures in [313], focused on different methods of mathematical modeling [10,12, 16-18].

The current regulatory requirements don't apply to test method of exterior curtain walls of building's facade system. The current Russian standards concerning the methods of fire tests don't address specific construction solutions for exterior curtain walls with translucent elements and associated possible scenarios of fire, as well as the orientation of the thermal effect on such a structure $[3,4]$.

Objectives:

- $\quad$ to study fire resistance of translucent combined facade systems "Tehnokom" type Alucobond A2 projected on an object-"41-storey office building" in Moscow;

- $\quad$ to define possible fire hazard reduction facade system "Tehnokom".

A glass unit block was made of translucent single-chamber glass unit $38 \mathrm{~mm}$ thick. Execution scheme: external glass triplex 6.6.2 Stopsol Supersilver Clear (SSC) (produced by firm "Glaverbel" Belgium), spacer $16 \mathrm{~mm}$, inner glass-transparent glass "Pilkington" 10M1 tempered. Frame built from blocks of aluminum profiles HUEK (manufactured by "Eduard Huek \& co. KG GmbH", Germany).

The translucent filling decorative element is executed according to the following scheme:

sandwich panel type Alucobond A2, 4 mm thickness;

${ }^{\text {a }}$ Corresponding author : nedryshkin@gmail.com

This is an Open Access article distributed under the terms of the Creative Commons Attribution License 4.0, which permits unrestricted use, distribution, and reproduction in any medium, provided the original work is properly cited. 
sheet zinced steel thickness $0.55 \mathrm{~mm}$;

mineral plates of Rockwool, $150 \mathrm{~mm}$ thick, density $45 \mathrm{~kg} / \mathrm{m} 3$.

Rubber is laid along the length of the butt joints between blocks sample.

\section{Methods}

This system configuration made it possible to formulate a program to determine the feasibility of the application of the investigated translucent and combined facade systems in a building and to establish their conformity with the requirements of the specifications [18]. The work included of the following main steps:

1. The limits of fire resistance and fracture mechanism of the construction are explored under the conditions of standard tests;

2. The application of compensatory measures are established:

- the device for sprinkling (water) of a glass unit of a translucent construction from the inside on the floor of the fire;

- the aluminum structure, facings for fire protection of fasteners of a facade and decrease in temperature of a flame of the external fire (fig. 1 shows);

- the device in internal cavities of decorative elements of fire retardant belts and fireproof data processing of cavities for the purpose of prevention of distribution of a flame;

3. Fire tests are conducted for fragments of facade system with compensating activities and determining whether application of the investigated system.

4. Identify the possibility of spreading fire in the floors of the building.

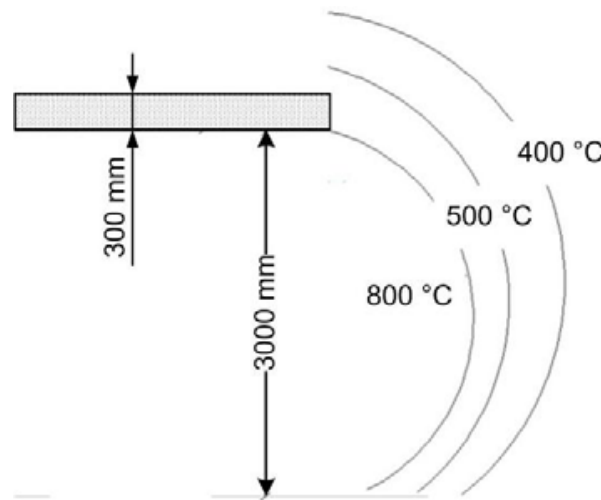

without aluminum substructure

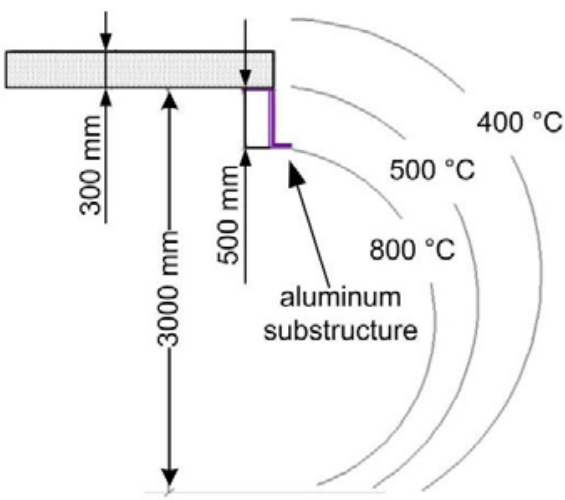

with aluminum substructure

Figure 1. Aluminum substructure for decrease heat temperatures influence on the facade systems.

Fire tests give experimental data about of fire resistance limit of translucent constructions.

The purpose of the fire test is to establish the time from the beginning of fire exposure before the limit state (loss of integrity).

It was assumed that the integrity of the facade glass unit on the floor where there is a fire was trouble and facade of the upstream floors subjected to fire exposure. Fire resistance of facade system in mode external fire was investigated. The aim is to investigate ways of distribution of fire from floor to floor.

Fragment of facade set up upside towards the fire effects. After the beginning of the tests the temperature regime calculated by equation 1 [3-5]:

$$
T=660\left(1-0.687 \times e^{-0.32 t}-0.313 \times e^{-3.8 t}\right)+20
$$

where: $\mathrm{T}$ is the temperature in the furnace, the appropriate time $\mathrm{t},{ }^{\circ} \mathrm{c}$;

t-time, calculated from the start of the test, min. 


\section{Results}

From fire testing are identify what own fire resistance limit of the translucent facade construction on the grounds of loss of integrity during the external fire without the use of compensating measures be E9. The limit state (loss of bearing capacity) of elements of the mullion-transom constructions doesn't occur.

On the basis of the external temperature ratio and standard fire in case of fire inside the building limit of fire resistance of structures on the basis of loss of integrity will be no more E4 ... E6 [3]. The results give right to believe that the fire is able to spread on the facade of the building with a speed of not less than 1 floor for 13-15 minutes.

The purpose of the device for sprinkling of the glass from the inside during a fire is: reduce heat flow affecting the construction, increase the limit of facade system resistance by reducing room temperature. After the destruction of the glass unit on the floor of fire continued sprinkling water reduces the temperature of the flame, affecting the higher floor.

To test for fire resistance was applied the kerosene. 5 burners installed in the furnace, plug in a phased manner to increase the temperature. The calculation showed that convective flow through opening, with account for sprinkling water equal to $328.4^{\circ} \mathrm{C}$ (fig. 2 shows). The data obtained are not contrary to the calculations made by other methods [16, 17]. Flame temperature of external fire affecting the facade block floors above the fire floor is accepted maximum and equal to $328.4^{\circ} \mathrm{C}$.

The amount of heat released during the combustion of kerosene (KO-30):

$$
Q=q \times m=46 \times 10^{6} \times 0.042=1.9 \mathrm{MJ} / \mathrm{s}
$$

where: $\mathrm{q}$ - low heating value, $\mathrm{MJ} / \mathrm{kg}$;

$\mathrm{m}$ - kerosene consumption, $\mathrm{kg} / \mathrm{s}$.

The amount of heat from the flame per unit time taking into account the heat losses attributable to cladding structures (wall, floor, ceiling).

$$
\begin{gathered}
Q_{\Sigma}=Q_{c}+Q_{p}+Q_{p e r} \\
Q_{c}=a_{c}\left(t_{m}-t_{c}\right) F_{c} \\
Q_{p}=a_{p}\left(t_{m}-t_{p}\right) F_{p} \\
Q_{p e r}=a_{p e r}\left(t_{m}-t_{p e r}\right) F_{p e r}
\end{gathered}
$$

where: Q - quantity of heat, J;

$\mathrm{a}_{\mathrm{c}, \mathrm{p}, \mathrm{per}}$ - average heat transfer coefficients, $\mathrm{W} / \mathrm{m}^{2}{ }^{\circ} \mathrm{C}$;

$\mathrm{t}_{\mathrm{m}}$ - average temperature volume of the gas environment in the room, ${ }^{\circ} \mathrm{C}$;

$\mathrm{t}_{\mathrm{c}, \mathrm{p} \text {,per }}$ - average temperature of the surfaces respectively of the walls, floor and ceilings, ${ }^{\circ} \mathrm{C}$.

$$
a_{c}=0.2 \lambda \div H \times(G r P r)^{\frac{1}{3}}\left\{\operatorname{Pr}^{\frac{2}{3}}\left[2.14(1+N)+\operatorname{Pr}^{\frac{2}{3}}\right]\right\} \times(1+N)
$$

where: $\mathrm{Gr}-$ Grashof number;

Pr - Prandtl number;

$\mathrm{N}$ - analogue of the number Kirpicheva characterizing radiation-conductive heat transfer in the boundary layer;

$\lambda$ - heat-conduction coefficient, $\mathrm{W} / \mathrm{mK}$.

Under splintering on the floor of water flow of $0.9 \ldots 1.11 / \mathrm{s}(90 \%$ of surface area):

$$
a_{p e r}=1.4 \frac{\lambda}{r} \operatorname{Pr}^{\frac{1}{3}} \operatorname{Re}^{\frac{1}{2}}+13.3\left(\frac{\sigma F \tau}{B}\right)
$$

where: $\sigma=5.7 \times 10^{-8}-$ blackbody coefficient, $\mathrm{W} /\left(\mathrm{m}^{2} \mathrm{~K}^{4}\right)$;

$\mathrm{B}-$ analogue of the Bouguer number, which characterizes the effective optical density in the boundary layer;

$\mathrm{r}$ - distance from frontal point on the surface of the slab, $\mathrm{m}$;

$\mathrm{Re}-$ Reynolds number $(\mathrm{Re}=2350)$.

$$
a_{p}=0.7 \times a_{c}
$$


The surface temperature of the plane wall:

$$
t_{c 2}=t_{c 1}-\frac{Q_{\text {light }}}{\frac{\lambda F \tau}{\sigma}}
$$

where: $\lambda$ - coefficient of thermal conductivity, is made under the assumption that a plane wall consists of a mixture of water and air, $\mathrm{W} / \mathrm{mK}$;

$\tau$ - time to take in the calculation, c;

$\sigma$ - planar wall thickness, m;

$\mathrm{t}_{\mathrm{c} 1}$ - the high temperature inside the room in case of fire, ${ }^{\circ} \mathrm{C}$;

$\mathrm{Q}_{\text {light }}$ - amount of heat coming through the light, J;

$\mathrm{F}$ - conventional flat wall area, increased by the total surface area of the drops of water supplied to irrigation, $\mathrm{m}^{2}$.

$$
\begin{gathered}
F=S_{\text {light }}+\sum S^{\text {drops }} \\
N_{k}=V_{\text {water }} / V_{\text {drops }} \\
V_{\text {drops }}=\frac{4}{3} \pi R^{3} \\
\sum S^{\text {drops }}=\frac{4}{3} \pi R^{2} N_{k} \\
Q_{\text {light }}=Q-Q \Sigma
\end{gathered}
$$

where: $\mathrm{S}_{\text {light }}-$ area of light, $\mathrm{m}^{2}$;

$\sum S^{\text {water }}$ - total surface area of water drops applied to the irrigation of the window opening, $\mathrm{m}^{2}$;

$\mathrm{V}_{\text {water }}$ - volume of water supplied for irrigation per unit of time, $\mathrm{c}$;

$\mathrm{V}_{\text {drops }}$ - volume of one drop of water, $\mathrm{m}^{3}$;

$\mathrm{Q}_{\text {light }}-$ amount of heat transported through the light per unit time, $\mathrm{J} / \mathrm{s} \times \mathrm{m}^{2}[3]$.

Thus:

- $\quad$ flame temperature near glass unit floor from upper the floor of the fire after the destruction of the glass unit on the floor of the fire will not exceeds $328.4{ }^{\circ} \mathrm{C}$.

- for carrying out tests temperature on all surface of the tested fragment (in the fire camera of the test furnace) is accepted by the highest (equal to the temperature at the bottom) $-330 \pm 5{ }^{\circ} \mathrm{C}$.

The fire resistance is equal to $65 \mathrm{E}$, under splintering on the floor of water flow of $0.9 \ldots 1.1 \mathrm{l} / \mathrm{s}$. This is according to specifications.

The calculation showed that the application of the regular glass unit with sprinkling device allows to reduce the temperature of the flame of the fire affecting to the upper glass unit floor to a value lower than the loss of bearing capacity aluminum mullion-transom constructions.

Failsafety sprinkler should be not less than 0.99 [3]. To compensate for the risk of release of sprinklers inoperable and reducing the temperature of the flame over the opening on the floor of the fire are encouraged to install in ceiling fire barrier of each floor. In this case, the calculated temperature distribution near the opening with destroyed glass unit if there is fire countermeasure shut-off failure of sprinkling systems is presented in Figure 2. As a fire-retardant coating was selected composition of the intumescent type. The thickness of a layer of a fireproof covering has to provide filling coked cellular material the gap which is formed as a result of deformations and transfer material of a decorative element to group not extending a flame on a surface (RP 1) [3]. 


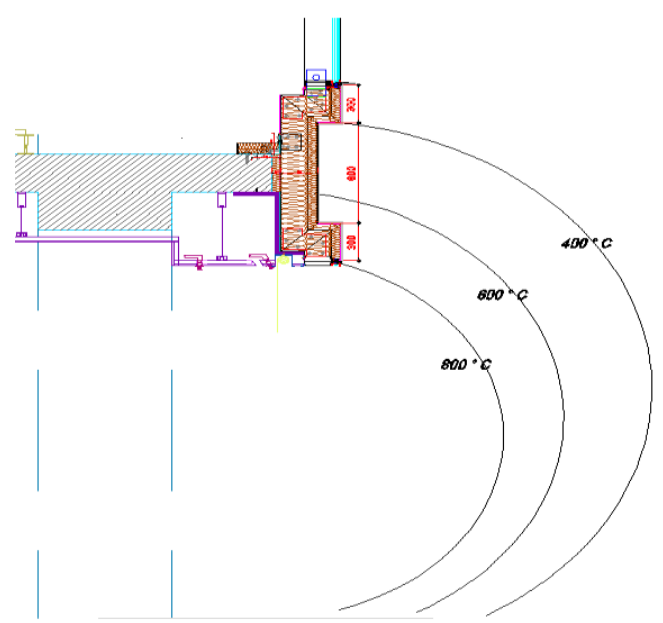

Figure 2. Temperature distribution of convective flow near the doorway with destroyed glass unit.

\section{Discussion}

Presented at the fire tests of samples of translucent facade construction fall short of specifications for the following reasons:

1) own limit of fire resistance of construction under external fire tests $-E 9$, when a fire indoors $E 4$ - E 6, i.e. from one floor to another building fire may spread over $13 \ldots 15 \mathrm{~min}$;

2) own limit of fire resistance of metal fasteners facade constructions is $\mathrm{R} 14$, which could lead to the collapse of mullion-transom constructions;

3) decoration of the facade can serve as a source of flame propagation for hidden cavities, which makes it difficult to extinguish the fire and contributes to its spread along the facade.

To ensure compliance with the requirements of the specifications developed the following compensating event:

1) sprinkling not less than $90 \%$ of the surface covering of the doorway on each floor with water by an automatic sprinkler system with $0.9 \ldots 1.1 \mathrm{l} / \mathrm{s}$;

2) device in the ceiling part of the fire the cutoff of a width not less than $500 \mathrm{~mm}$, the limit of fire resistance must not be less than the value REI 60;

3) provision of fire resistance limit node of an adjunction to overlappings facade system building at least REI 60;

4) providing the limit of fire resistance of the fastening elements of façade system not less than $\mathrm{R}$ 60 ;

5) device inside fire isolate leaf of steel with a thickness of $0.55 \mathrm{~mm}$ and steal covered with a coat of paint intumescent flame retardant composition $1 \mathrm{~mm}$ thick.

\section{Conclusions}

The research of translucent combined facade systems "Tehnokom" with the compensatory activities has shown that the implementation of these activities ensures compliance with regulatory requirements of facade systems.

\section{References}

1. Yu. Nikitin, V. Murgul, N. Vatin, V, Pukhkal, AMM, 680, 481-485 (2014)

2. D. Nemova, V. Murgul, A. Golik, E. Chizhov, V. Pukhkal, N. Vatin, JAES, 12(1), 37-44 (2014) 
3. O. Lamkin, M. Gravit, O. Nedryshkin, Journal "Construction of Unique Buildings and Structures", 11(38), 42-58 (2015)

4. M. Gravit, V. Gumenyuk, O. Nedryshkin, Procedia Engineering, 117, 114-118 (2015)

5. A. Krivtcov, V. Kazakova, I. Mingalimov, P. Bogdanov, I. Nitsa, Journal "Construction of Unique Buildings and Structures", 6(33), 34-46 (2015)

6. M. Kaziev, E. Zubkova, V. Bezborodov, Tekhnologii tekhnosfernoj bezopasnosti, 6 (58) (2014)

7. A. Gusev, V. Zigern-Korn, I. Molchadskiy, Tekhnologii stroitelstva, 4 (59), 20-24 (2008)

8. I. Khasanov, I. Molchadskiy, K. Goltsov, A. Fire safety, 5, 36-47 (2006)

9. M. Gravit, Fire and Explosion Safety, 11, 42-45 (2014)

10. M. Heinisuo, M. Laasonen, J. Outinen, J. Hietaniemi, Application of Structural Fire Construction, 405-410 (2011)

11. M. Lazarevska, M. Cvetkovska, M. Knezevic, A. Gavriloska, M. Milanovic, V. Murgul, N. Vatin, Applied Mechanics and Materials, 627, 276-282 (2014)

12. I. Romanenkov, V. Zigern-Korn, Fire resistance of building structures of effective materials, (Moscow, (1984)

13. J. Hana, L. Lin, J. Penga, Y. Hongxing, Energy and Buildings, 204-209 (2013)

14. L. Gaillard, S. Giroux-Julien, C. Menezo, H. Pabiou, Journal of Fundamentals of Renewable Energy and Applications, 5 (2012)

15. N. Vatin, A. Gorshkov, D. Nemova, A. Staritcyna, D. Tarasova, AMR, 941 - 944, 905-920 (2014)

16. S. Puzach, A. Smagin, O. Lebedchenko, Ye. Abakumov. New ideas about the calculation of the required time to evacuate people and the effectiveness of the use of portable filter self-rescuers for the evacuation fires. Monograph, (Moscow, (2007)

17. Yu. Koshmarov, M. Bashkirtsev. Thermodynamics and heat transfer in the fire case, (Moscow, (1987)

18. O. Halyavin, M. Gravit, A. Pryanikova, Materials Science Forum with international participation, 34, 22-25 (2015) 